\title{
シャント制振のための電磁アクチュエータのセンサレスパラメータ推定
}

池亀 $~^{*}{ }^{*} 1$, 高木 賢太郎 ${ }^{*} 2$, 井上 剛志 ${ }^{* 2}$, 軸屋 一郎 ${ }^{*} 3$

\section{Sensor-less parameter estimation of electromagnetic actuator for shunt damping}

\author{
Toru IKEGAME ${ }^{* 1}$, Kentaro TAKAGI ${ }^{* 2}$, Tsuyoshi INOUE ${ }^{* 2}$ and Ichiro JIKUYA*3 \\ ${ }^{*} 1,{ }^{*} 2$ Department of Mechanical Science and Engineering, Nagoya University \\ Furo-cho, Chikusa-ku, Nagoya-shi, Aichi 464-8603, Japan \\ ${ }^{*} 3$ Department of Aerospace Engineering, Nagoya University \\ Furo-cho, Chikusa-ku, Nagoya-shi, Aichi 464-8603, Japan
}

\section{Received 28 December 2014}

\begin{abstract}
Electromagnetic shunt damping is a sensor-less passive damping technique using an electromagnetic actuator. The accurate values of the parameters of the system are essentially required for designing a controller in the damping technique. This paper proposes a parameter estimation method of an electromagnetic actuator attached to a mechanical structure in order to use for electromagnetic shunt damping. The electromagnetic actuator attached to the structure is modeled as the system including the mechanical and electrical systems which are connected by the electromechanical coupling coefficient. This paper points out a remark on the estimation: The frequency response of the electrical admittance especially neighborhood the natural frequency of the mechanical structure shows an electro-mechanically resonant feature, which does not appear in the pure electrical system without the electromechanical coupling. By applying least squares method to the frequency response data of the electrical admittance neighborhood the natural frequency, the parameters of the mechanical system and the electromechanical coupling coefficient as well as the electrical parameters can be estimated. The proposed estimation method requires only measurements of the frequency response of the electrical admittance across the terminals of the electromagnetic actuator. Therefore, both the parameter estimation and the electromagnetic shunt damping are possible to perform without any displacement or velocity sensors, or any additional actuators. In order to verify the effectiveness of the proposed method, the experiments of parameter estimation and of electromagnetic shunt damping are performed. The experimental results show that the proposed method is effective to estimate the parameters of the electromagnetic actuator without use of any other sensors.
\end{abstract}

Key words : Electromagnetic actuator, Parameter estimation, Smart structure, Sensor-less, Least squares method, Vibration control, Dynamic absorber

1. 緒言

一般に電磁アクチュエータはコイルに流れる電流によって電磁力を発生して動作するまた，とくに永久磁石 を利用した電磁アクチュエータは磁場中でのコイルの相対的な運動によって発生する誘導起電力をセンサとして 用いることができる.さらに，アクチュエータとセンサを同時に使用するセルフセンシングなアクチュエータと

No. 15-00006 [DOI:10.1299/transjsme.15-00006], J-STAGE Advance Publication date : 3 April, 2015

${ }^{* 1} 1$ 学生員, 名古屋大学 大学院 工学研究科 機械理工学専攻（ ₹ 464-8603 愛知県名古屋市千種区不老町）

*2 正員, 名古屋大学 大学院 工学研究科 機械理工学専攻

*3 名古屋大学 大学院工学研究科航空宇宙工学専攻

E-mail of corresponding author: t_ikegame@nuem.nagoya-u.ac.jp 
Ikegame, Takagi, Inoue and Jikuya, Transactions of the JSME (in Japanese), Vol.81, No.825 (2015)

しても用いることができるといった，電気エネルギーと運動エネルギーが相互に変換可能なアクチュエータであ る (Boldea and Nasar, 1999)(Hanson and Levesley, 2004)(Preumont, 2011)(Rao, 2011). この特性を利用し，単一の電 磁アクチュエータを構成しているコイルの端子間に適切な外部電気回路 (シャント回路) を接続することでセンサ レスな制振を行う手法 (電磁シャント制振) が研究されている (井上他, 2004)(Behrens, et al., 2005)(Niederberger, et al., 2006)(Niu, et al., 2009)(高木他, 2012).

電磁シャント制振は振動エネルギーを電気エネルギーに変換し，回路の抵抗素子によって熱エネルギーに変換， 消散することで制振が行われる。そのため, 電磁アクチュエータの端子間を短絡するだけでも, コイルの内部抵 抗によって若干の制振効果が得られる.さらに大きな制振効果を得る方法の一つとして，シャント回路に電気共 振回路を導入することで振動エネルギーからより多くの電気エネルギーを取り出し，消散する方法がある. この とき, 電磁アクチュエータにはコイルのインダクタンスが含まれているので, 共振回路を作るためにシャント回 路にはキャパシタを用いる (井上他, 2004)(Behrens, et al., 2005)(Niederberger, et al., 2006)(Niu, et al., 2009)(高木他, 2012). ここでの共振回路のキャパシタは動吸振器の補助質量と同様の役割を果たしているため, 共振回路を用い た手法は動吸振器と同様の振動制御を行うことができることを意味している (井上他, 2004)(Zhu, et al.,2013). 動吸 振器の利点はノミナル性能が良く, 共振ピークを落とすことができることである. しかし, 固有角振動数の変化 などに対して性能が容易に劣化するためロバスト性能が悪く, 正確なパラメータ值が必要となる欠点がある. 共 振回路を用いた手法は動吸振器と同様の手法を用いてコントローラを設計するため, 電磁アクチュエータの精度 の高いパラメータ值が必要となる.

本論文では, 電磁アクチュエータの端子間の電流・電圧計測のみに基づくパラメータ推定手法を提案する. 実験 装置は文献 (井上他, 2004)(Behrens, et al., 2005)(Niederberger, et al., 2006)(高木他, 2012) 等と同様, 一自由度のマス バネダンパ系の振動構造物にコイルと永久磁石で構成された電磁アクチュエータを取り付けた装置を用いる. 初 めに, 電磁アクチュエータのモデル化を行い, 系の支配方程式を導出し, 電磁アクチュエータの電流と電圧の比 である電気アドミタンス伝達関数を導出する. 次に, 電磁アクチュエータの電流・電圧計測, 具体的には, 電気 アドミタンス周波数応答計測のみに基づき, コイルのインダクタンス, 内部抵抗や構造物の固有角振動数, 減衰 比，そして電気機械結合係数といった制振で用いるコントローラの設計に必要なパラメータ值をすべて推定する 手法を提案する。なお，これらのパラメータはLCRメータや変位センサ等を用いることで個別の測定が可能であ る (高木他, 2012). しかし, 本論文で提案する手法は一度の電気アドミタンス計測のみによってパラメータ推定を 行うことができるため, 個別に推定を行うより短時間, 低コストかつ変位・速度センサや加振用のアクチュエー タ等が不要といった利点がある. また, センサレスでパラメータ推定を行うことができるため, センサレスで行 うことができる電磁シャント制振と合わせて, パラメータ推定から制振までを一切の変位・速度計測無しで行う ことが可能となる. 最後に推定したパラメータ值の妥当性を検証するために電磁シャント制振実験を行う.シャ ント回路の最適設計には推定したパラメータ值と動吸振器における定点理論を用いて行う (井上他, 2004)(高木他, 2012). そして最適設計を行ったシャント回路を取り付けた場合と, 取り付けずに端子間を開放した場合の制振性 能を比較することでパラメータ推定值の妥当性を確認する.

\section{2. モデリン グ}

本節では電気アドミタンスの周波数応答計測のみに基づくパラメータ推定を行うために, 電磁アクチュエータ が取り付けられた構造物のモデル化を行う。そして, モデルから支配方程式と電気アドミタンス伝達関数を導出 する.

\section{$2 \cdot 1$ 支配方程式}

電磁アクチュエータが取り付けられた図 1 で表される一自由度マスバネダンパ系の振動構造物を考える.この システムの機械系, 電気機械結合系, 電気系のモデルをそれぞれ考える.

\section{$\mathbf{2 \cdot 1 \cdot 1}$ 機械系}

構造物の加速度, 速度, 変位をそれぞれ $\ddot{x}\left[\mathrm{~m} / \mathrm{s}^{2}\right], \dot{x}[\mathrm{~m} / \mathrm{s}], x[\mathrm{~m}]$ と定義する. 構造物のパラメータは $m[\mathrm{~kg}]$ が質量, $c[\mathrm{~N} \cdot \mathrm{s} / \mathrm{m}]$ が粘性係数, $k[\mathrm{~N} / \mathrm{m}]$ が弾性係数を示す. また, 構造物には外乱 $f_{d}[\mathrm{~N}]$ と磁場中においてコイルに流れる 


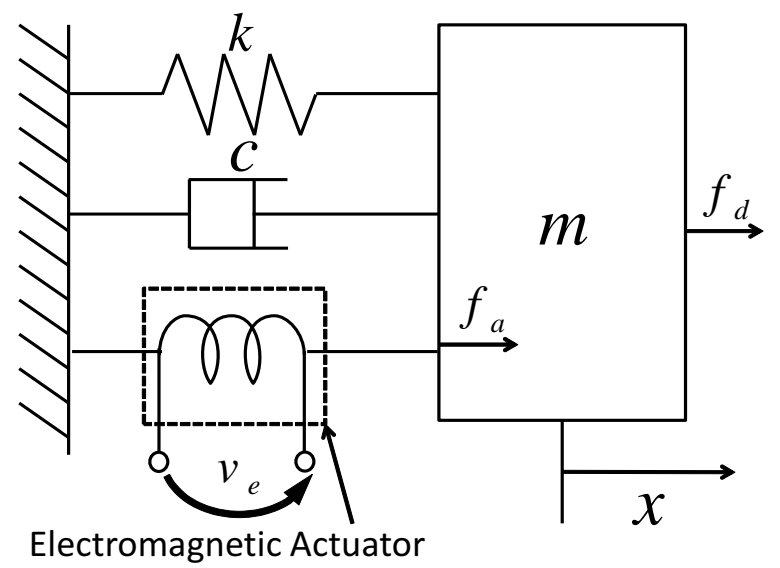

Fig. 1 Mechanical system model

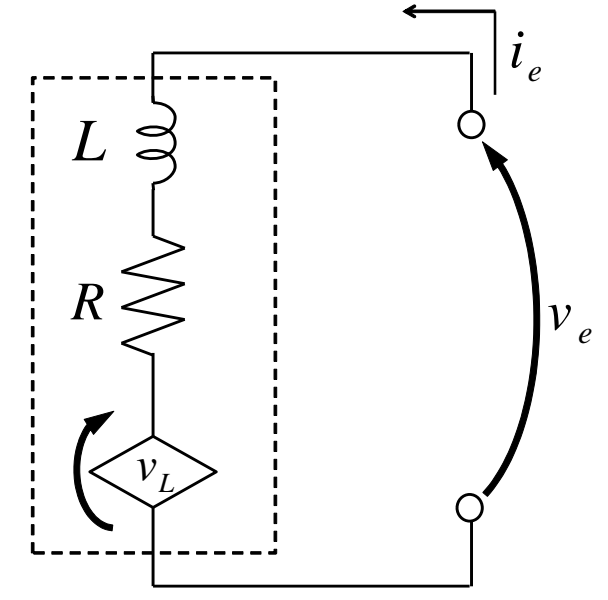

Fig. 2 Electrical system model

電流に比例した電磁力 $f_{a}[\mathrm{~N}]$ が発生する. 変位が十分に小さく, 線形運動であると仮定すると図 1 の運動方程式は 次式が導出される.

$$
m \ddot{x}(t)+c \dot{x}(t)+k x(t)=f_{a}(t)+f_{d}(t)
$$

\section{$2 \cdot 1 \cdot 2$ 電気機械結合系}

電磁アクチュエータの磁束むらが小さいと仮定すると, 電磁力 $f_{a}$ と誘導起電力 $v_{L}[\mathrm{~V}]$ は以下の二式が成り立つ (井上他, 2004). 式中の $\phi\left[\mathrm{N} / \mathrm{A}\right.$ or V. s/m] は電気機械結合係数, $i_{e}[\mathrm{~A}]$ は電磁アクチュエータに流れる電流を表す.

$$
\begin{aligned}
& f_{a}(t)=\phi i_{e}(t) \\
& v_{L}(t)=\phi \dot{x}(t)
\end{aligned}
$$

\section{$2 \cdot 1 \cdot 3$ 電気系}

電磁アクチュエータはコイルと永久磁石で構成されているため, 電気系モデルは図 2 のようにコイルのインダ クタンスと内部抵抗, 振動によって発生した逆起電力を表す電圧源が直列につながれたモデルで表される (井上他, 2004)(Behrens, et al., 2005)(Niederberger, et al., 2006)(高木他, 2012). $L[\mathrm{H}]$ はコイルのインダクタンス，R[S] はコ イルの内部抵抗, $v_{e}[\mathrm{~V}]$ は電磁アクチュエータの端子間電圧と定義すると, 図 2 の回路方程式として次式が導出さ れる.

$$
L \frac{d i_{e}(t)}{d t}+R i_{e}(t)=v_{e}(t)-v_{L}(t)
$$

\section{$2 \cdot 2$ 電気アドミタンス伝達関数}

2.1 節では機械系および電気系の支配方程式, ならびに電磁力と誘導起電力の式を導出した。ここで, 式 (3) か ら速度 $\dot{x}$ と誘導起電力 $v_{L}$ を測定することで容易に電気機械結合係数 $\phi$ を推定できることがわかる. しかし, 電磁 シャント制振では変位・速度センサを用いないため, パラメータ推定でも変位・速度センサを使用せずに推定を 行うことが望まれる. 変位・速度センサや加振用アクチュエータを使用せずにパラメータ推定を行うために, 電 磁アクチュエータの端子間における電流・電圧のみを用いた推定手法を提案する.

加振用アクチュエータを使用しないため外乱 $f_{d}=0$ とし, 式(1) (4)にラプラス変換を行うと, 電圧 $v_{e}$ から電流 $i_{e}$ に関する電気アドミタンス伝達関数 $Y_{e}(s)\left[\Omega^{-1}\right]$ は式 (5) が導出される. 本論文では $v_{e}(t)$ のラプラス变換を $V_{e}(s)$ のように大文字で表す.

$$
Y_{e}(s)=\frac{I_{e}(s)}{V_{e}(s)}=\frac{1}{L s+R+\frac{\bar{\phi}^{2} s}{s^{2}+2 \zeta_{n} \omega_{n} s+\omega_{n}^{2}}}
$$

ここで $\omega_{n}[\mathrm{rad} / \mathrm{s}](=\sqrt{k / m})$ は構造物の固有角振動数, $\zeta_{n}[-](=c / \sqrt{4 m k})$ は減衰比, $\bar{\phi}\left[\mathrm{N} / \mathrm{A} / \mathrm{kg}^{\frac{1}{2}}\right.$ or V. s/m/ $\left.\mathrm{kg}^{\frac{1}{2}}\right](=$ $\phi / \sqrt{m})$ は質量によって正規化された電気機械結合係数である. 
ここで, 電流・電圧の計測のみでパラメータ推定可能であるかを検証するために, $Y_{e}(s)$ が電気機械結合係数 $\bar{\phi}$ の有無によってどのように変化するか確認する. 式 (5)に $\bar{\phi}=0$ を代入して得られる電気アドミタンス伝達関数を $Y_{0}(s)=(L s+R)^{-1}$ とおく. $Y_{e}(j \omega)$ と $Y_{0}(j \omega)$ のボード線図を図 3 に例示する. 赤線が $Y_{e}(j \omega)$ を表し電気機械結合 係数が有る場合に相当し, 青線は $Y_{0}(j \omega)$ を表し電気機械結合係数が無い場合に相当する.ただし, それぞれのパ ラメータの值は以降のパラメータ推定の結果として得られた表 3 の非線形最小二乗法 (Nonlinear least square) の結 果を用いる. 図 3 から明らかなように, 構造物の固有振動数付近 $\left(8[\mathrm{~Hz}]\right.$ 付近) において $Y_{e}(j \omega)$ と $Y_{0}(j \omega)$ に大き な差が見られ, 構造物の固有振動数から外れると $(4[\mathrm{~Hz}]$ 以下, $12[\mathrm{~Hz}]$ 以上) 両者にほとんど差が見られないこと がわかる. 従って, 構造物の固有角振動数付近の $Y_{e}(j \omega)$ には, 電気系パラメータ $L, R$ だけでなく, 電気機械結 合係数 $\bar{\phi}$ と機械系パラメータ $\zeta_{n}, \omega_{n}$ が顕著に寄与すると予想できる. 以降では, 構造物の固有角振動数付近で $Y_{e}(j \omega)$ を計測し, パラメータ推定を行う手法を提案する.
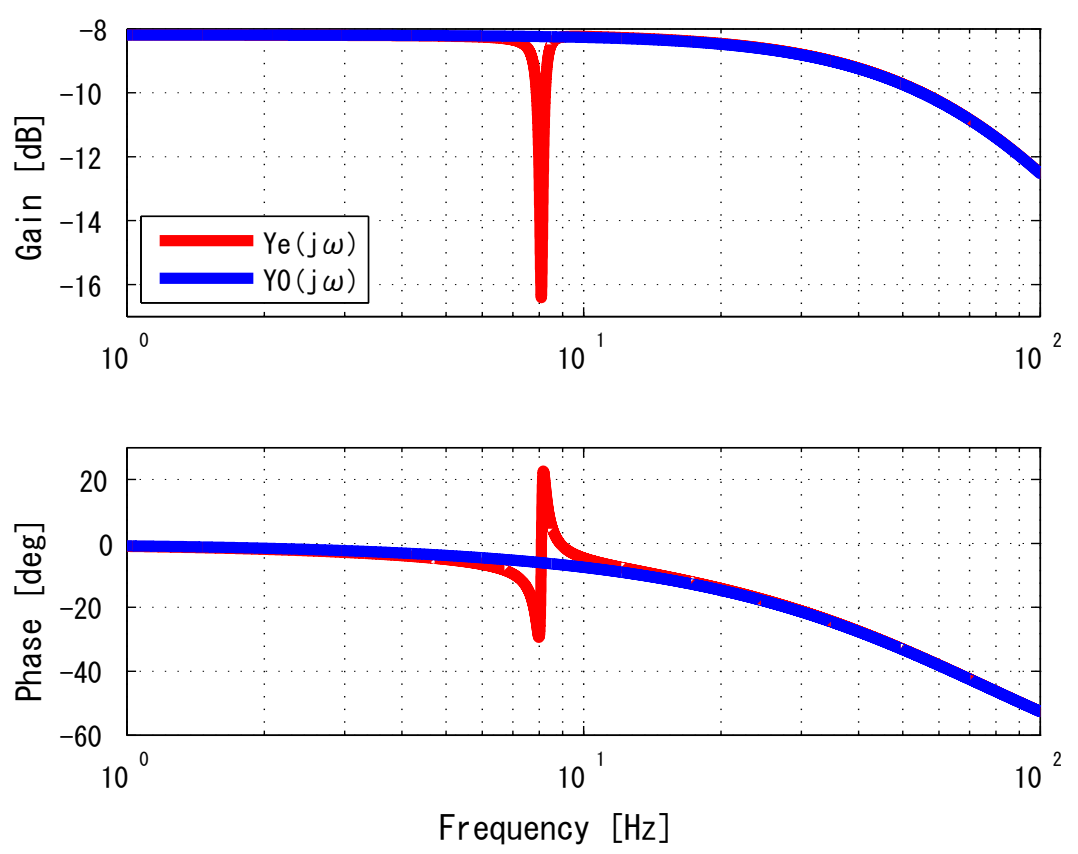

Fig. 3 Bode diagram of $Y_{e}(j \omega)$ and $Y_{0}(j \omega)$

\section{3. パラメータ推定手法}

本節では式 (5) の電気アドミタンスモデルに含まれるパラメータ值を推定する手法を提案する. 計測データは構 造物の固有角振動数付近の複素電気アドミタンスであり, パラメータ推定問題は重みつきの非線形最小二乗法に 帰着できることを示す. 非線形最小二乗法は数值最適化により計算されるが, 計算の初期值が必要であることか ら, 評価関数を修正して線形最小二乗法に帰着する手法も提案する.

\section{1 非線形最小二乗法}

本節では式 (5) の電気アドミタンスモデルに含まれるパラメータを推定する手法を提案する． $Y_{e}(s)$ のパラメー タへの依存性を明示するために, $Y_{e}\left(j \omega ; \boldsymbol{\theta}_{n l s}\right)$ と表記する. $\boldsymbol{\theta}_{n l s} \in \mathbb{R}^{5}$ はパラメータをベクトル表記したものである.

$$
\boldsymbol{\theta}_{n l s}:=\left[L, R, \zeta_{n}, \omega_{n}, \bar{\phi}\right]^{\mathrm{T}}
$$

計測データは構造物の固有角振動数付近の複素電気アドミタンス $Y_{s}\left(j \omega_{s}[k]\right),\left(k=1,2, \ldots, N_{s}\right)$ であり, $Y_{e}\left(j \omega_{s}[k] ; \boldsymbol{\theta}_{n l s}\right)$ をあてはめることを考える.ここで $k$ は周波数サンプル番号, $N_{s}$ は周波数サンプル点数を表す. 式 (5) から明ら かなように電気アドミタンス $Y_{e}(s)$ は積分特性を持ち, したがって $1 / Y_{e}(s)$ は微分特性を持つ. そこで, 周波数領 
域で平均的に特性評価をするために式 (8) のような積分特性をもつ重み関数 $W(s)$ を導入し, 式 (7) に示す重みつ き非線形最小二乗法によりパラメータベクトル $\boldsymbol{\theta}_{n l s}$ を決定することとする.

$$
\begin{aligned}
& \min _{\boldsymbol{\theta}_{n l s}} \sum_{k=1}^{N_{s}}\left|\left(\frac{1}{Y_{s}\left(j \omega_{s}[k]\right)}-\frac{1}{Y_{e}\left(j \omega_{s}[k] ; \boldsymbol{\theta}_{n l s}\right)}\right) W\left(j \omega_{s}[k]\right)\right|^{2} \\
& W\left(j \omega_{s}[k]\right):=\frac{1}{j \omega_{s}[k]}
\end{aligned}
$$

表記の簡単化と数值計算の都合上，式 (7) は次式のようにベクトル表記する.

$$
\min _{\boldsymbol{\theta}_{n l s}}\left\|\boldsymbol{f}\left(\boldsymbol{\theta}_{n l s}\right)-\boldsymbol{b}_{n l s}\right\|^{2}
$$

ここで, $\boldsymbol{f} \in \mathbb{C}^{N_{s}}, \boldsymbol{b}_{n l s} \in \mathbb{C}^{N_{s}}$ はベクトルであり，その $k$ 行目をそれぞれ $f_{k}, b_{n l s k},\left(k=1,2, \ldots, N_{s}\right)$ とおくと, $f_{k}, b_{n l s k}$ は次 式で表される.

$$
\begin{aligned}
f_{k} & :=\frac{1}{Y_{e}\left(j \omega_{s}[k] ; \boldsymbol{\theta}_{n l s}\right)} W\left(j \omega_{s}[k]\right) \\
b_{n l s k} & :=\frac{1}{Y_{s}\left(j \omega_{s}[k]\right)} W\left(j \omega_{s}[k]\right)
\end{aligned}
$$

\section{2 線形最小二乗法}

非線形最小二乗法は数值最適化により計算されるが, 計算の初期值が必要であることから, 評価関数を修正し て線形最小二乗法に帰着する手法も提案する. 伝達関数が有理式となるように式 (5) 変形した式を次式に示す.

$$
Y_{e}(s)=\frac{s^{2}+2 \zeta_{n} \omega_{n} s+\omega_{n}^{2}}{L s^{3}+\left(R+2 L \zeta_{n} \omega_{n}\right) s^{2}+\left(2 R \zeta_{n} \omega_{n}+L \omega_{n}^{2}+\bar{\phi}^{2}\right) s+R \omega_{n}^{2}}
$$

式 (12)の分母多項式，分子多項式をそれぞれ以下のように表記する.

$$
\begin{aligned}
Y_{e}(s) & =\frac{s^{2}+a s+b}{c s^{3}+d s^{2}+e s+f} \\
& =\frac{g_{\text {num }}(s)}{g_{\text {den }}(s)} \\
g_{\text {nит }}(s) & :=s^{2}+2 \zeta_{n} \omega_{n} s+\omega_{n}^{2} \\
g_{\text {den }}(s) & :=L s^{3}+\left(R+2 L \zeta_{n} \omega_{n}\right) s^{2}+\left(2 R \zeta_{n} \omega_{n}+L \omega_{n}^{2}+\bar{\phi}^{2}\right) s+R \omega_{n}^{2}
\end{aligned}
$$

そして式 (7) の代わりに以下のような評価関数を導入し，パラメータ $a \sim f$ に関する線形最小二乗問題を考える.

$$
\min _{a \sim f} \sum_{k=1}^{N_{s}}\left|\left(\frac{g_{\text {num }}\left(j \omega_{s}[k]\right)}{Y_{s}\left(j \omega_{s}[k]\right)}-g_{\text {den }}\left(j \omega_{s}[k]\right)\right) W_{l}\left(j \omega_{s}[k]\right)\right|^{2}
$$

ただし, $k$ は周波数サンプル番号, $N_{s}$ は周波数サンプル点数を表し, 式(15) と式(16)に $s=j \omega_{s}[k]$ を代入した. 重 み関数 $W_{l}\left(j \omega_{s}[k]\right)$ は非線形最小二乗法と同様，次式のような積分特性を持つものを定義する.

$$
W_{l}\left(j \omega_{s}[k]\right):=\frac{1}{j \omega_{s}[k]}
$$

次にパラメータベクトル $\boldsymbol{\theta}_{l s} \in \mathbb{R}^{6}$ を以下のように定義する.

$$
\boldsymbol{\theta}_{l s}:=\left[\frac{1}{\omega_{n}^{2}}, \frac{2 \zeta_{n}}{\omega_{n}}, \frac{L}{\omega_{n}^{2}}, \frac{R}{\omega_{n}^{2}}+\frac{2 L \zeta_{n}}{\omega_{n}}, \frac{2 R \zeta_{n}}{\omega_{n}}+L+\frac{\bar{\phi}^{2}}{\omega_{n}^{2}}, R\right]^{\mathrm{T}}
$$

式(17) はベクトル $\boldsymbol{\theta}_{l s}$ を用いてパラメータに関してまとめると次式のように行列を用いて表すことができる.

$$
\min _{\boldsymbol{\theta}_{l s}}\left\|\boldsymbol{A} \boldsymbol{\theta}_{l s}-\boldsymbol{b}\right\|^{2}
$$

ここで, 行列 $\boldsymbol{A} \in \mathbb{C}^{N_{s} \times 6}$, ベクトル $\boldsymbol{b} \in \mathbb{C}^{N_{s}}$ の $k$ 行目をそれぞれ $A_{k}, b_{k},\left(k=1,2, \ldots, N_{s}\right)$ とおくと $A_{k}, b_{k}$ は次式で表される.

$$
\begin{aligned}
A_{k} & :=\left[\frac{\left(j \omega_{s}[k]\right)^{2}}{Y_{S}\left(j \omega_{s}[k]\right)}, \frac{j \omega_{s}[k]}{Y_{S}\left(j \omega_{s}[k]\right)},-\left(j \omega_{s}[k]\right)^{3},-\left(j \omega_{s}[k]\right)^{2},-j \omega_{s}[k],-1\right] W_{l}\left(j \omega_{s}[k]\right) \\
b_{k} & :=-\frac{1}{Y_{S}\left(j \omega_{s}[k]\right)} W_{l}\left(j \omega_{s}[k]\right)
\end{aligned}
$$


式 (20) で示した線形最小二乗問題の解は次式で与えられる.

$$
\boldsymbol{\theta}_{\text {lsopt }}=\left(\boldsymbol{A}^{*} \boldsymbol{A}+\overline{\boldsymbol{A}^{*} \boldsymbol{A}}\right)^{-1}\left(\boldsymbol{A}^{*} \boldsymbol{b}+\overline{\boldsymbol{A}^{*} \boldsymbol{b}}\right)
$$

ここで, $\boldsymbol{A}^{*}$ は $\boldsymbol{A}$ の共役転置, $\bar{A}$ は $\boldsymbol{A}$ の各要素を共役複素数としたものを表す.なお，逆行列を計算する際の数值 誤差が問題となる場合が多い。そこで, 推定值のオーダーが既知の場合に限り， $\boldsymbol{\theta}_{l s}$ の各要素のオーダーと同程度 な值を対角成分とした実対角行列 $\boldsymbol{S}$ を用いて次式のようにスケーリングを行うとよい.

$$
\boldsymbol{\theta}_{l s}=\boldsymbol{S} \boldsymbol{\theta}_{s l s}
$$

式 (24) を用いることで式 (20) の線形最小二乗問題の解は次式のようになる.

$$
\boldsymbol{\theta}_{\text {lsopt }}=\boldsymbol{S}\left(\boldsymbol{S}^{\mathrm{T}}\left(\boldsymbol{A}^{*} \boldsymbol{A}+\overline{\boldsymbol{A}^{*} \boldsymbol{A}}\right) \boldsymbol{S}\right)^{-1} \boldsymbol{S}^{\mathrm{T}}\left(\boldsymbol{A}^{*} \boldsymbol{b}+\overline{\boldsymbol{A}^{*} \boldsymbol{b}}\right)
$$

$\boldsymbol{\theta}_{\text {lsopt }}$ の各要素を $\theta_{i}(i=1,2, \ldots, 6)$ とおく. 式 (25) で得られた值を式 (19) に代入し, 代数方程式を解くことで電磁了 クチュエータのパラメータ推定值が求められる. しかし, 式(19)より6 個の式から 5 個の未知数を推定するため, この代数方程式は過決定である. そのため, 解は複数考えられるがここでは次式のように線形最小二乗法の解を 決定する.

$$
\begin{aligned}
L & =\frac{\theta_{3}}{\theta_{1}} \\
R & =\theta_{6} \\
\zeta_{n} & =\frac{\theta_{2}}{2 \sqrt{\theta_{1}}} \\
\omega_{n} & =\frac{1}{\sqrt{\theta_{1}}} \\
\bar{\phi} & =\sqrt{\frac{\theta_{5}}{\theta_{1}}-\frac{\theta_{3}}{\theta_{1}^{2}}-\theta_{6} \frac{\theta_{2}}{\theta_{1}}}
\end{aligned}
$$

\section{4. パラメータ推定実験}

本節ではパラメータ推定実験を行う。初めに, 電磁アクチュエータの電気アドミタンス計測のための実験装置と 実験方法を示す.そして, 計測した電気アドミタンスと前節の推定手法を用いて, 電磁アクチュエータの物理パラ メータ值を推定する。

\section{$4 \cdot 1$ 実験装置}

電気アドミタンス計測実験装置の概略図を図 4 に，実際に使用する実験装置を図 5 に示す．本実験では直動べア リングにより水平一自由度の運動に制限された台車に, 制振用の電磁アクチュエータと外乱用の電磁アクチュエー タが取り付けられている．制振用の電磁アクチュエータには，電流計測用の抵抗 $R_{\text {in }}$ と計装アンプ $\left(\right.$ 倍率 $\left.K_{\text {in }}\right)$, パ ワーOP アンプ (倍率 $K_{\text {out }}$ ) からなるアナログ回路が接続されており, 図 4 中の破線内に示す. また, アナログ回路 の素子值は表 1 に示す. 素子值の選定方法に関しては, 文献 (高木他, 2012) を参照されたい. 電磁アクチュエータ に流れる電流 $i_{e}$ は直接測定することが難しいため, アナログ回路の抵抗 $R_{i n}$ と計装アンプ $K_{i n}$ にって, 電流を電 圧 $v_{y}=R_{i n} K_{i n} i_{e}$ に変換して計測を行う．また， $v_{y} に 1 /\left(R_{i n} K_{i n}\right)$ をかけることで，電流 $i_{e}$ を得ることができる. な お，パラメータ推定実験では外乱用電磁アクチュエータを使用しないため，外乱用電磁アクチュエータの端子間は 影響を及ぼさないように開放しておく. なお, 筆者らの先行研究では, 本実験装置に対して LCR メーと变位セ ンサを用いて個別にパラメータ測定を行った結果もあり, 本実験装置の公称值として表 2 に示す (高木他, 2012). 


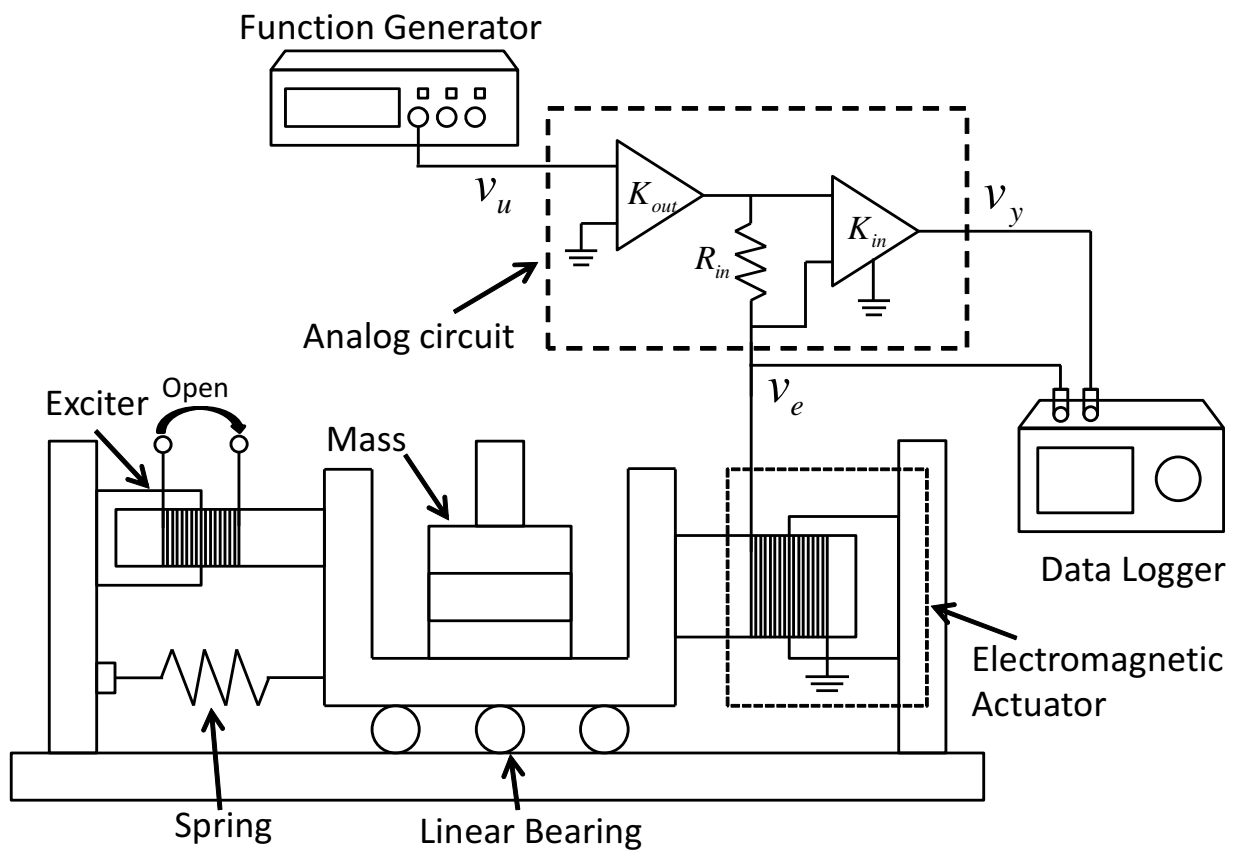

Fig. 4 Experimental setup for the admittance measurement

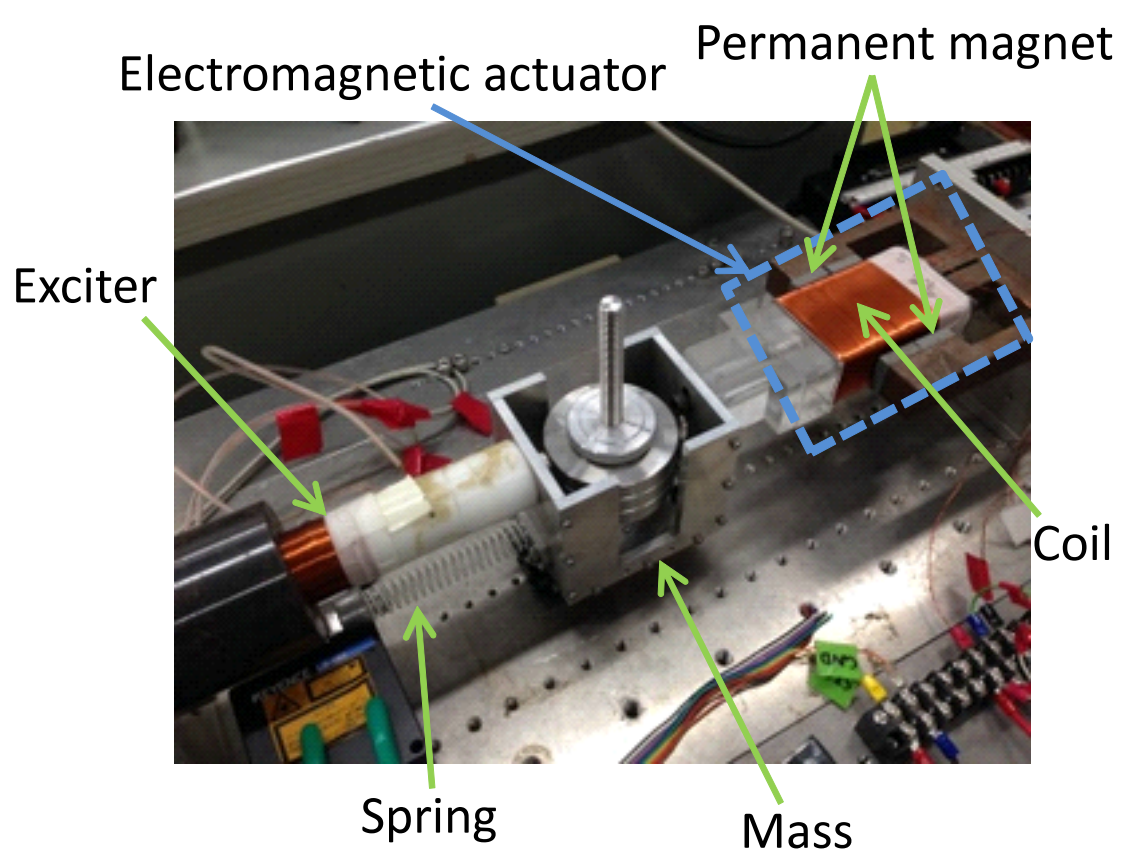

Fig. 5 Picture of the experimental setup

Table 1 Parameters of the analog circuit

\begin{tabular}{ccc}
\hline \hline$R_{\text {in }}$ & 0.0996 & {$[\Omega]$} \\
$K_{\text {in }}$ & 99.23 & {$[\mathrm{~V} / \mathrm{V}]$} \\
$K_{\text {out }}$ & 1 & {$[\mathrm{~V} / \mathrm{V}]$} \\
\hline
\end{tabular}

Table 2 Nominal parameters of the experimental setup

\begin{tabular}{ccc}
\hline \hline$m$ & 1.71 & {$[\mathrm{~kg}]$} \\
$c$ & 1.05 & {$[\mathrm{Ns} / \mathrm{m}]$} \\
$k$ & $4.38 \times 10^{3}$ & {$[\mathrm{~N} / \mathrm{m}]$} \\
$\phi$ & 1.88 & {$[\mathrm{~N} / \mathrm{A}, \mathrm{Vs} / \mathrm{m}]$} \\
$L$ & $5.83 \times 10^{-3}$ & {$[\mathrm{H}]$} \\
$R$ & 2.5 & {$[\Omega]$} \\
\hline \hline
\end{tabular}




\section{$4 \cdot 2$ 実験手順}

1. 電磁アクチュエータの端子間電圧と電流を計測して, 電気アドミタンス周波数応答を算出する. 初めにファ ンクションジェネレータを用いて, 図 4 中の $v_{u}$ にスイープ正弦波の入力電圧を加える. そして, データロ ガーを用いて電磁アクチュエータの端子間電圧 $v_{e}$ と, 電流 $i_{e}$ を測定する代わりに計装アンプから出る電圧 $v_{y}\left(=R_{i n} K_{i n} i_{e}\right)$ を測定する. ファンクションジェネレータの印加電圧を $250[\mathrm{mV}]$, データロガーのサンプリン グ周波数を $500[\mathrm{~Hz}]$ で 65536 点を計測する. 本実験で用いる機械系の固有振動数は $8 \mathrm{~Hz}$ 付近であるので，固 有振動数付近である $4 \sim 12 \mathrm{~Hz}$ の間で計測を行う.

2. 計測を 5 回行い, $v_{e}$ と $v_{y}$ の平均クロススペクトルを $v_{e}$ の平均パワースペクトルで割り, $V_{y} / V_{e}$ の周波数応答 を求める. 得られた $V_{y} / V_{e}$ の周波数応答に $1 /\left(R_{i n} K_{i n}\right)$ をかけることで, 電圧 $V_{y}$ が電流 $I_{e}$ に変換され, 所望の 複素電気アドミタンス $Y_{s}\left(j \omega_{s}[k]\right)=I_{e} / V_{e}$ が得られる.

3. 得られた複素アドミタンス $Y_{s}\left(j \omega_{s}[k]\right)$ に対して，3.2 節の線形最小二乗法を用いて推定を行い，得られた推定 值を 3.1 節の非線形最小二乗法の初期值としてパラメータを推定する. なお, 線形最小二乗法のスケーリン グは $S=\operatorname{diag}\left[10^{-2}, 10^{-4}, 10^{-5}, 10^{-7}, 10^{-4}, 10^{0}\right]$ とした。これは実験装置のパラメータ $L, R, \zeta_{n}, \omega_{n}, \bar{\phi}$ のオーダーを， それぞれ $10^{-3}, 10^{0}, 10^{-3}, 10^{1}, 10^{0}$ と見積もったためである. 非線形最小二乗法における数值最適化計算には数 值最適化ソフトウェアを用いる。本研究では Matlab の Optimization Toolbox にあるコマンド 1sqnonlin を使用 する (MathWorks, 2015).

\section{$4 \cdot 3$ 実験結果と考察}

実験によって得られた電気アドミタンスの計測データとパラメータ推定結果を用いたモデルの応答との比較を行 う. 表 3 に線形最小二乗法と非線形最小二乗法それぞれによるパラメータ推定結果を示す. 次に計測データと応答 モデルを重辇きしたものを図 6 と図 7 に示す. 図 6 は複素平面上における $1 /\left(j \omega Y_{e}(j \omega)\right)$ のベクトル軌跡, 図 7 は電気アドミタンス伝達関数 $Y_{e}(j \omega)$ のボード線図である。ここでベクトル軌跡の $1 /\left(j \omega Y_{e}(j \omega)\right)$ は式 (7) で示した 非線形最小二乗法によるパラメータ推定で使用した評価関数である. 図 6, 図 7 ともに青い点は計測した電気アド ミタンス, 赤い破線と実線はそれぞれ線形最小二乗法と非線形最小二乗法によって推定したモデルの応答である.

Table 3 Estimated parameters

\begin{tabular}{cccc}
\hline \hline Parameters & Linear least square & Nonlinear least square & Dimension \\
$L$ & 0.00568 & 0.00535 & {$[\mathrm{H}]$} \\
$R$ & 2.56 & 2.57 & {$[\Omega]$} \\
$\zeta_{n}$ & 0.00814 & 0.00705 & {$[-]$} \\
$\omega_{n}$ & 50.8 & 50.8 & {$[\mathrm{rad} / \mathrm{s}]$} \\
$\bar{\phi}$ & 1.76 & 1.70 & {$\left[\mathrm{~N} / \mathrm{A} / \mathrm{kg}^{1 / 2}, \mathrm{Vs} / \mathrm{m} / \mathrm{kg}^{1 / 2}\right]$} \\
\hline \hline
\end{tabular}

図 7 は破線と実線に違いが見られないが，図 6 では実験データへの適合度合いに違いが見られる。ここで，線 形最小二乗法と非線形最小二乗法の評価関数を比較すると, 非線形最小二乗法の評価関数の方がアドミタンスの 推定誤差を小さくするという物理的意味がはっきりしている。そこで, 非線形最小二乗法の評価関数に基づき図 6 を対比すると, 周波数領域における平均的な推定誤差が小さいので非線形最小二乗法の方がパラメータ推定精度 が高いことが確認できる. また, 表 3 より線形最小二乗法と非線形最小二乗法では, 内部抵抗 $R$, 固有角振動数 $\omega_{n}$ にはほとんどずれが生じていないのに対し，他のパラメータ $L, \zeta_{n}, \bar{\phi}$ ではずれが生じているのがわかる. 


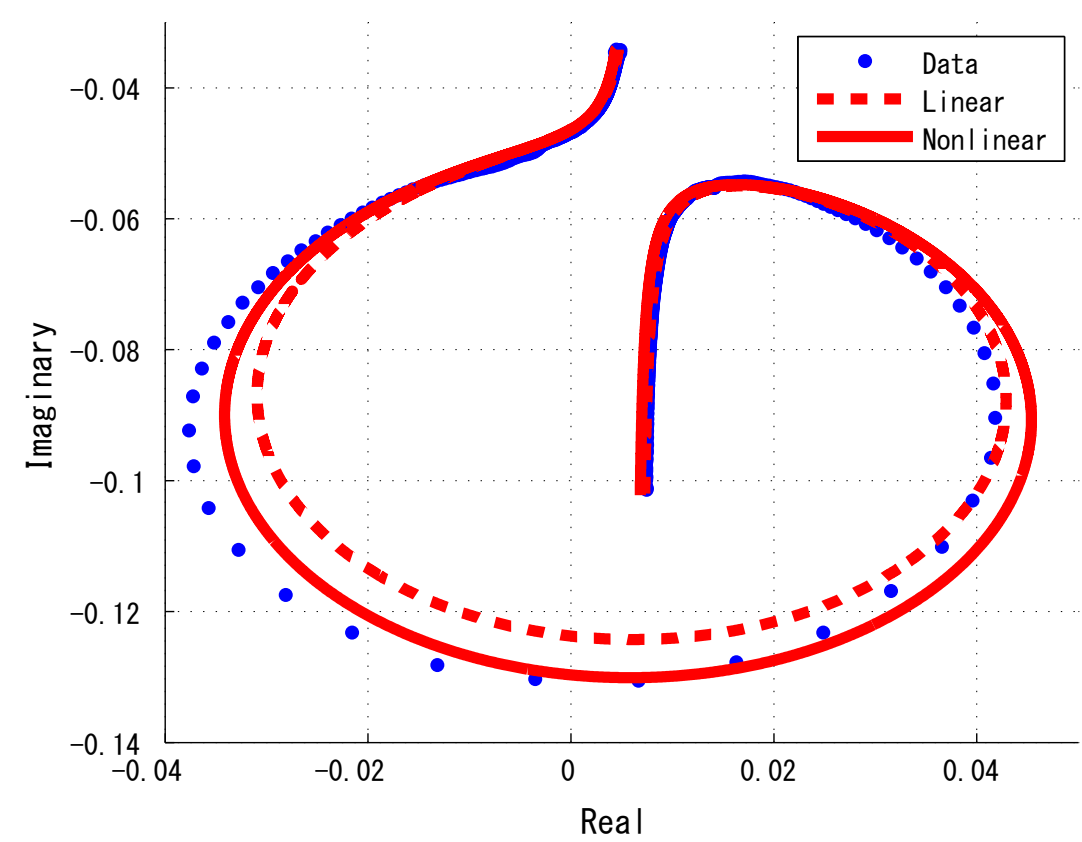

Fig. 6 Vector locus of the identified $1 /\left(\mathrm{j} \omega Y_{e}(\mathrm{j} \omega)\right)$
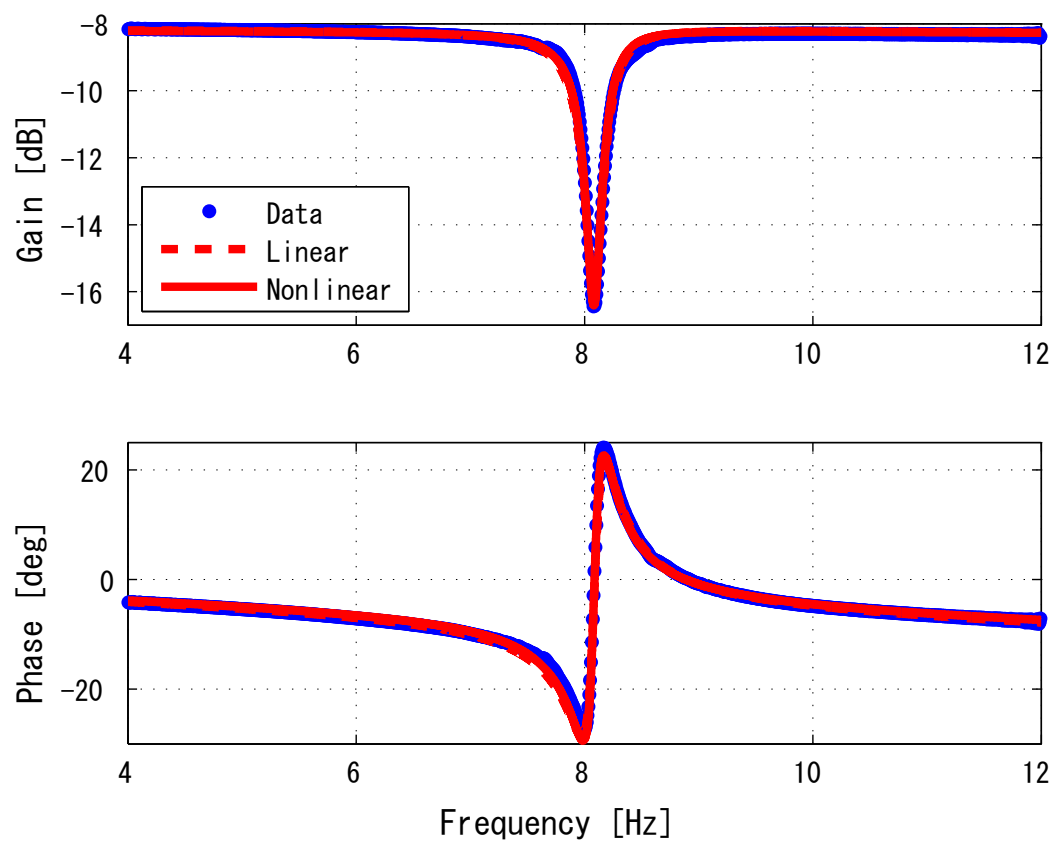

Fig. 7 Bode diagram of the identified $Y_{e}(\mathrm{j} \omega)$

\section{5. 推定值検証のための制振実験}

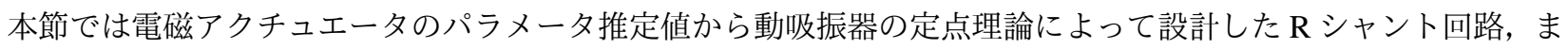
たは直列 RC シャント回路を取り付け，構造物に外乱を加え制振実験を行う．制振性能を見ることでパラメータ推 定実験の妥当性を検証する. 


\section{$5 \cdot 1$ 実験装置}

制振実験装置の概略図を図 8 に示す.制振用の電磁アクチュエータにはアナログ回路と DSP で構成された仮想 インピーダンス回路を接続する (高木他, 2012). 仮想インピーダンス回路を接続することによって, 所望のシャン 卜回路を電気的に接続することが可能となる. 図中の $v_{y}$ は DSP の AD ボードへの信号, $v_{u}$ は DSP の DA ボード からの信号を表す.シャント回路へ接続する所望のインピーダンスを $Z_{s}(s)$ とすると DSP に書き込むコントロー ラ $K(s)$ は次式で表される.

$$
K(s)=\frac{V_{u}(s)}{V_{y}(s)}=\frac{1}{R_{\text {in }} K_{\text {in }} K_{\text {out }}}\left(Z_{s}(s)-R_{\text {in }}\right)
$$

また, 外乱用の電磁アクチュエータには電流アンプとファンクションジェネレータが接続されており, 加振を行う ことができる．本実験では制振性能の評価のために，振動によって生じる台車の変位 $x$ をレーザ変位計によって 計測する. なお, 式(2)より, 電磁アクチュエータの最大出力は $f_{a}^{\max }=\phi i_{e}^{\max }$ により与えられる. ただし $i_{e}^{\max }$ はコ イルに流れる最大電流を表し，パワー OP アンプ $K_{\text {out }}(\mathrm{LM} 675$, Texas Instruments) により決定される．本実験装置 で使用する DSP の最大出力電圧が $10[\mathrm{~V}]$ 以下であり， パワー OP アンプの増幅率 $K_{\text {out }}$ は表 2 より $1[\mathrm{~V} / \mathrm{V}]$ なので, パワー OP アンプの最大出力電圧は 10[V] 以下である. パワー OP アンプのデータシート (Texas Instruments, 2015) によれば, パワー OP アンプを流れ出る最大電流はパワー OP アンプの最大出力電圧から決定され, $i_{e}^{\max }=3[\mathrm{~A}]$ と 見積もることができる. 電気機械結合変数 $\phi$ は提案手法では一意に定まらないが, 文献 (高木他, 2012) に記載さ れた手法などを用いることにより測定でき, ここでは表 2 の $\phi=1.88[\mathrm{~N} / \mathrm{A}]$ を考える. すると, 電磁アクチュエー タの最大出力は $f_{a}^{\max }=5.64[\mathrm{~N}]$ と見積もることができる.

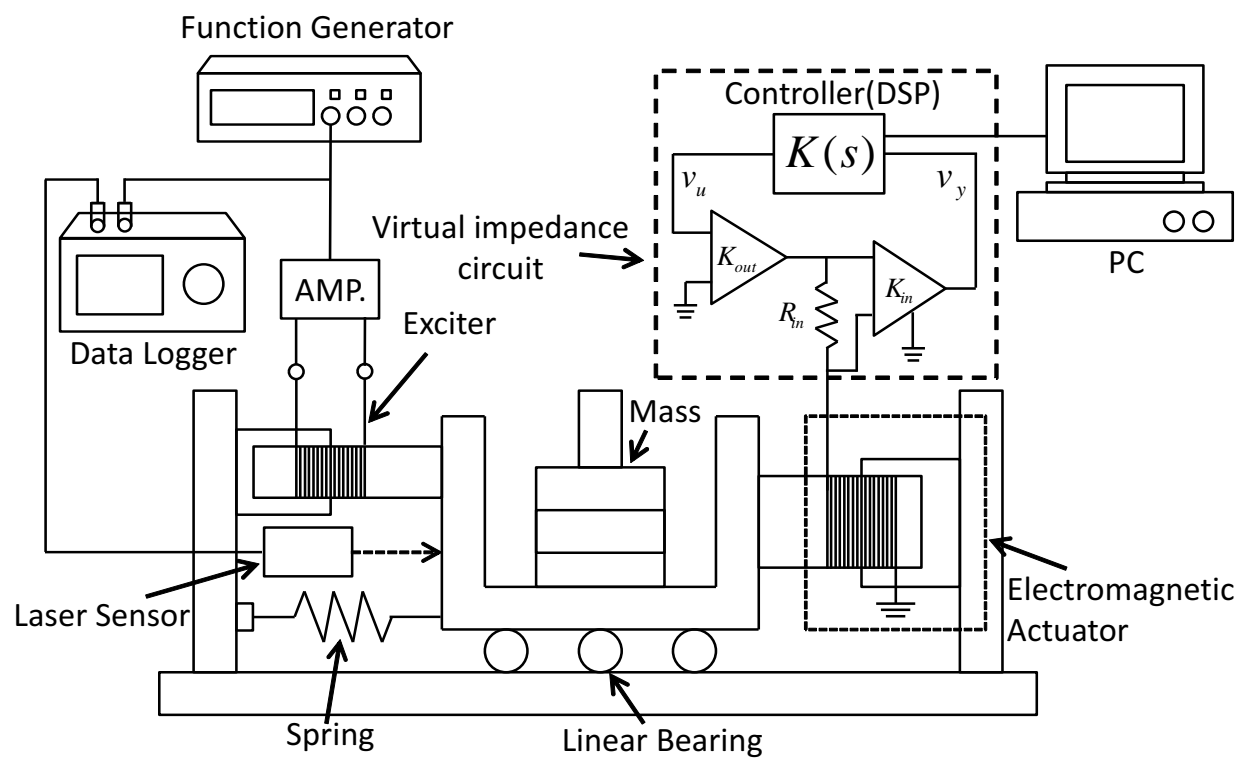

Fig. 8 Experimental setup for the shunt damping

\section{$5 \cdot 2$ シャント回路の最適設計}

シャント回路の最適設計值は, 動吸振器の定点理論によって導出した最適設計式に推定したパラメータ值を代 入することで求める. R シャント回路, $\mathrm{RC}$ シャント回路の最適設計式はそれぞれ式 (32)，式 (33) である (井上他, 2004)(高木他, 2012). これらの式に表 3 の非線形最小二乗法 (Nonlinear least square) によるパラメータ推定結果を 代入することで求めた最適設計值を表 4 に示す.

$$
R_{s}^{\text {opt(Rshunt })}=-R+L \sqrt{\frac{2 \omega_{n}^{2} L+\bar{\phi}^{2}}{2 L}}
$$




$$
\left\{\begin{array}{l}
R_{s}^{\text {opt }(R C \text { shunt })}=-R+\frac{\bar{\phi}}{4}\left(\sqrt{6 L+\sqrt{\frac{2 \bar{\phi}^{2} L}{\omega_{n}^{2}}}}+\sqrt{6 L-\sqrt{\frac{2 \bar{\phi}^{2} L}{\omega_{n}^{2}}}}\right) \\
C_{s}^{\text {opt }(R C \text { shunt })}=\frac{2}{2 \omega_{n}^{2} L-\bar{\phi}^{2}}
\end{array}\right.
$$

\begin{tabular}{|c|c|c|}
\hline$R_{S}^{\text {opt }(\text { Rshunt })}$ & -2.28 & {$[\Omega]$} \\
\hline$R_{S}^{\text {opt }(R C \text { shunt })}$ & -2.42 & {$[\Omega]$} \\
\hline$C_{s}^{o p t(R C s h u n t)}$ & 0.0810 & {$[\mathrm{~F}]$} \\
\hline
\end{tabular}

表 4 より，本実験装置では最適設計を行ったシャント回路の抵抗值が負の值を持つ。これは最適な回路全体の 抵抗值が制振用の電磁アクチュエータの内部抵抗より小さいために起こる現象である. そこで仮想インピーダン ス回路を接続することにより，仮想的にではあるがシャント回路に負值の抵抗を取り付けることが可能となる (高 木他, 2012).

シャント回路の最適設計における理論解析を行い，外力から変位までのモデルの周波数応答を図 9 に示す．黒 の点線が端子間開放時，青の破線が $\mathrm{R}$ シャント回路接続時，赤の実線が $\mathrm{RC}$ シャント回路接続時を表しており，

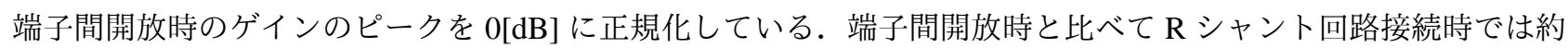
$-18.6[\mathrm{~dB}]$ の低減とピークの位置がずれることが確認できる. なお, 端子間開放時と比べてピークの位置がずれる 理由は，電磁アクチュエータに R シャント回路を接続することを，マスバネダンパ系にバネとダンパを直列に接 続するアナロジーで解釈した時に固有角振動数がずれる現象として説明できる (高木他, 2012). また，RCシャン 卜回路接続時では，1 個のピークが 2 個に分かれ，約 $-27.4[\mathrm{~dB}]$ の低減が確認できる.

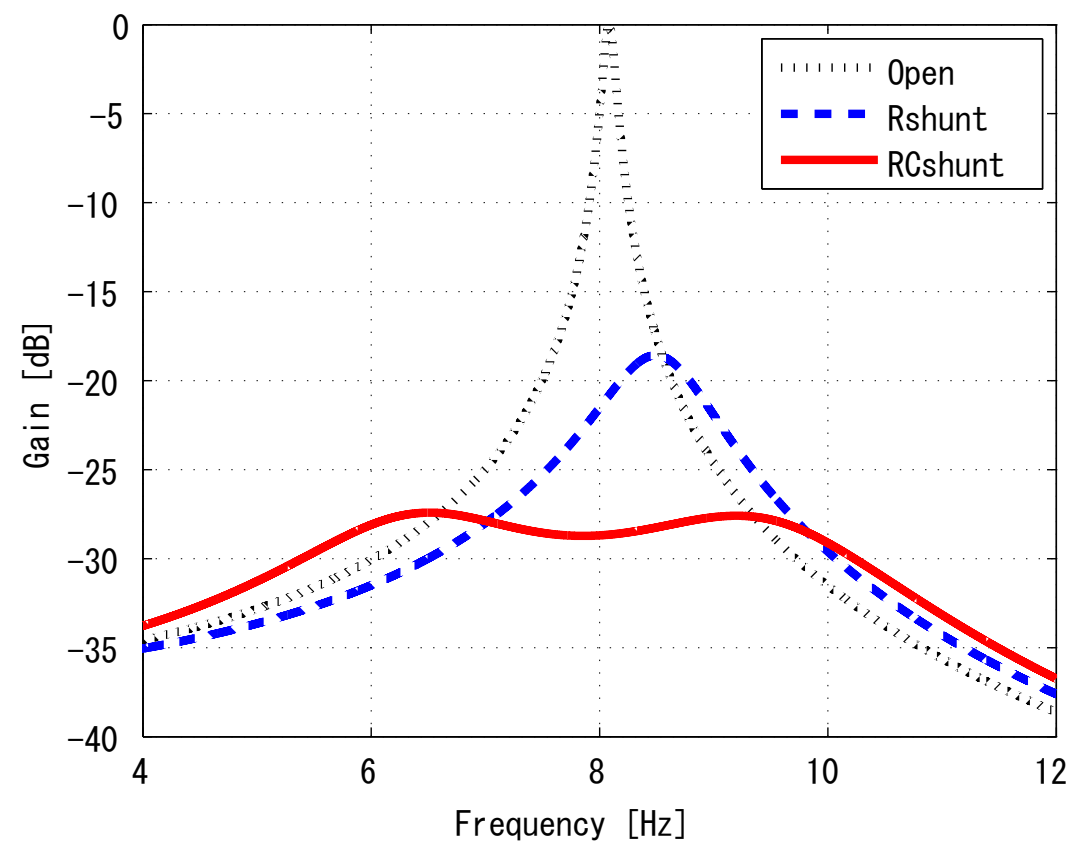

Fig. 9 Simulated frequency response 


\section{$5 \cdot 3$ 実験手順}

1. $\mathrm{R}$ シャント回路, RC シャント回路のインピーダンス $Z_{s}(s)$ はそれぞれ式 (34), 式 (35) で表される. 表 1 ，表 4 の值と式 (34) または式 (35) を用いて式 (31) で示したコントローラ $K(s)$ を決定する.そしてコントローラ $K(s)$ を Matlab の Simulink を用いて, DSPに書き込むことで仮想的にシャント回路を実現する.

$$
\begin{aligned}
Z_{s}^{\text {Rshunt }}(s) & =R_{s}^{\text {opt }(\text { Rshunt })} \\
Z_{s}^{R C \text { shunt }}(s) & =R_{s}^{\text {opt }(\text { RCshunt })}+\frac{1}{C_{s}^{\text {opt }(\text { RCshunt })} s}
\end{aligned}
$$

2. データロガーを用いて，ファングションジェネレータの印加電圧 (外乱) $f_{d}$ とレーザセンサによって計測した 変位 $x$ を計測する. ファンクションジェネレータの入力信号は $0.7[\mathrm{~V}]$ 振幅で $4 \sim 12[\mathrm{~Hz}]$ までを 81 秒間かけて スイープ加振を行う。サンプリング周波数は $200[\mathrm{~Hz}]$ で 16384 点とる.

3. 端子間開放と R シャント回路， RC シャント回路おける最適設計值を用いた場合の全部で 3 通りの制振実験 をそれぞれ 3 回計測を行う.

4. $f_{d}$ と $x$ の平均クロススペクトルを $f_{d}$ の平均パワースペクトルで割ることで, 3 通りの計測結果それぞれの外 乱 $f_{d}$ から変位 $x$ の周波数応答 $G_{x f_{d}}(j \omega)$ を求める.

\section{4 実験結果と考察}

端子間開放， R シャント回路， RC シャント回路を取り付けた場合それぞれにおける制振実験結果の時刻歴を図 10 に示す. それぞれの最大振幅は上から約 $5.13[\mathrm{~mm}]$, 約 $0.84[\mathrm{~mm}]$, 約 $0.39[\mathrm{~mm}]$ であり, 制振が行われているこ とが確認できる.

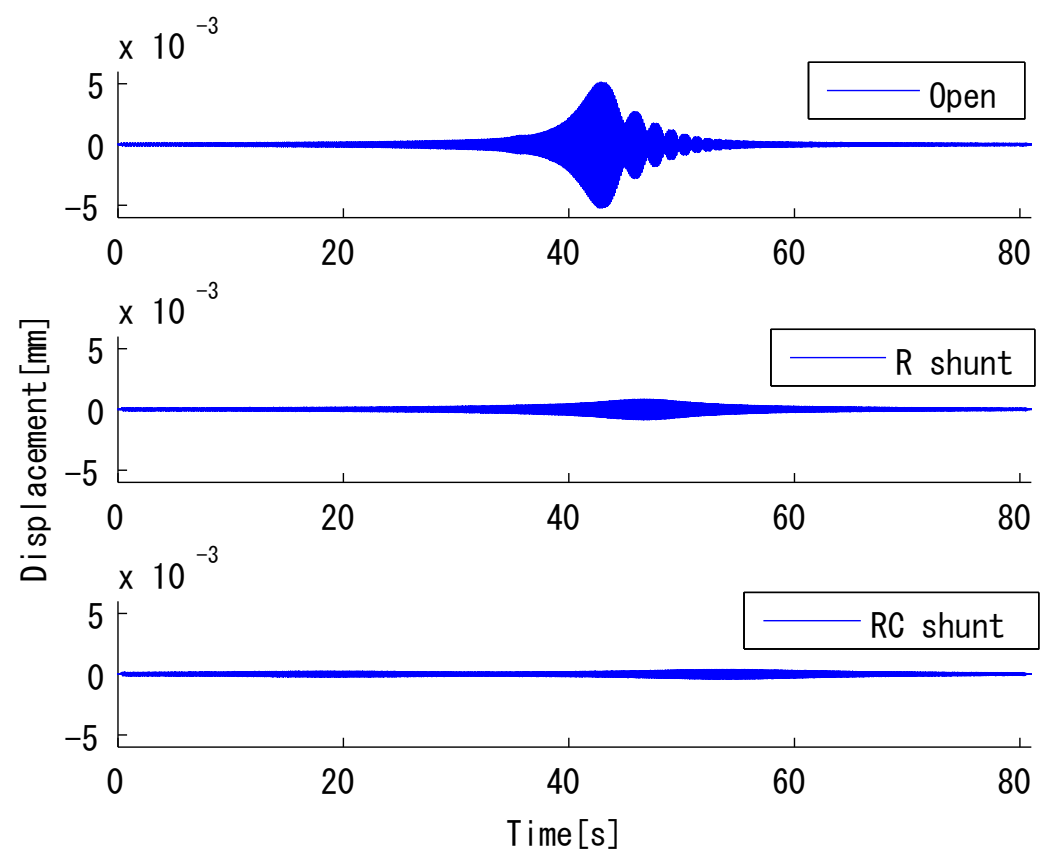

Fig. 10 Time response in the experiment

次に制振性能の比較のために端子間開放， $\mathrm{R}$ シャント回路， $\mathrm{RC}$ シャント回路におけるゲイン線図を重ね書きし， 端子間開放時のゲインのピークを $0[\mathrm{~dB}]$ に正規化したものを図 11 に示す。また，この時のコヒーレンスを図 12 に

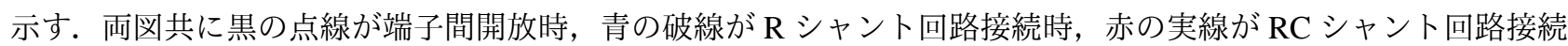
時である。 


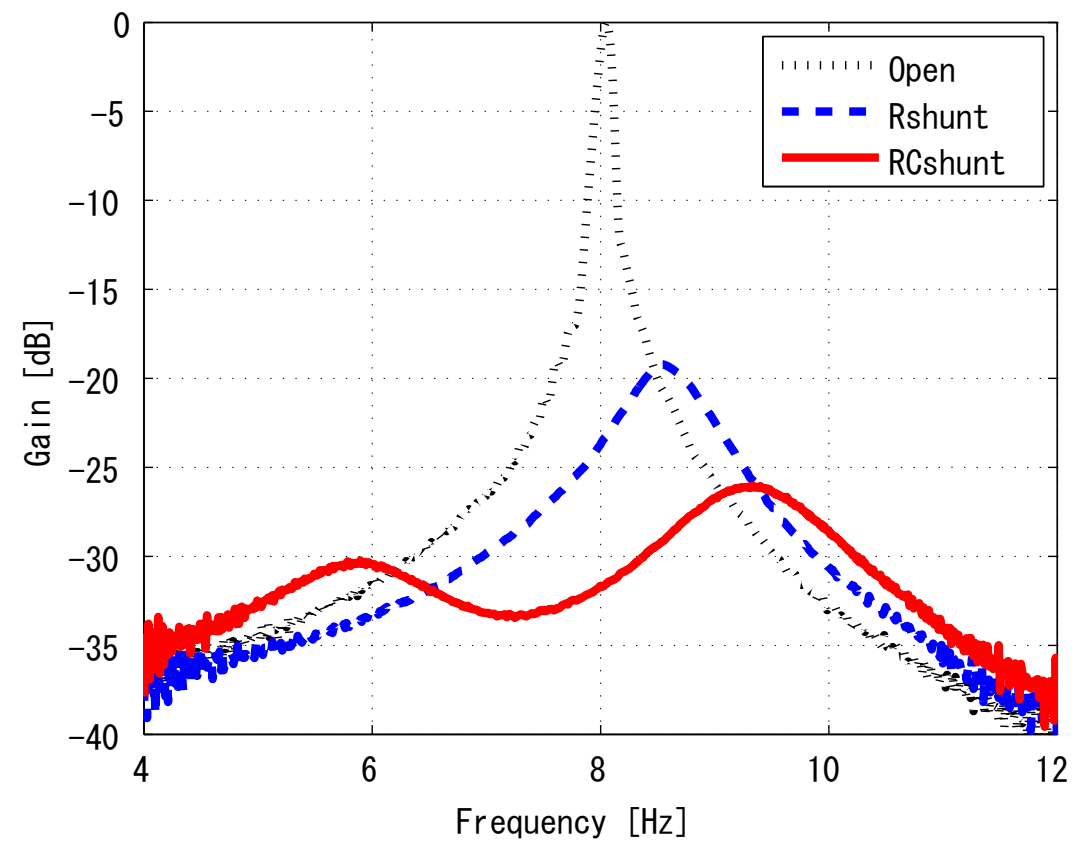

Fig. 11 Frequency response in the experiment

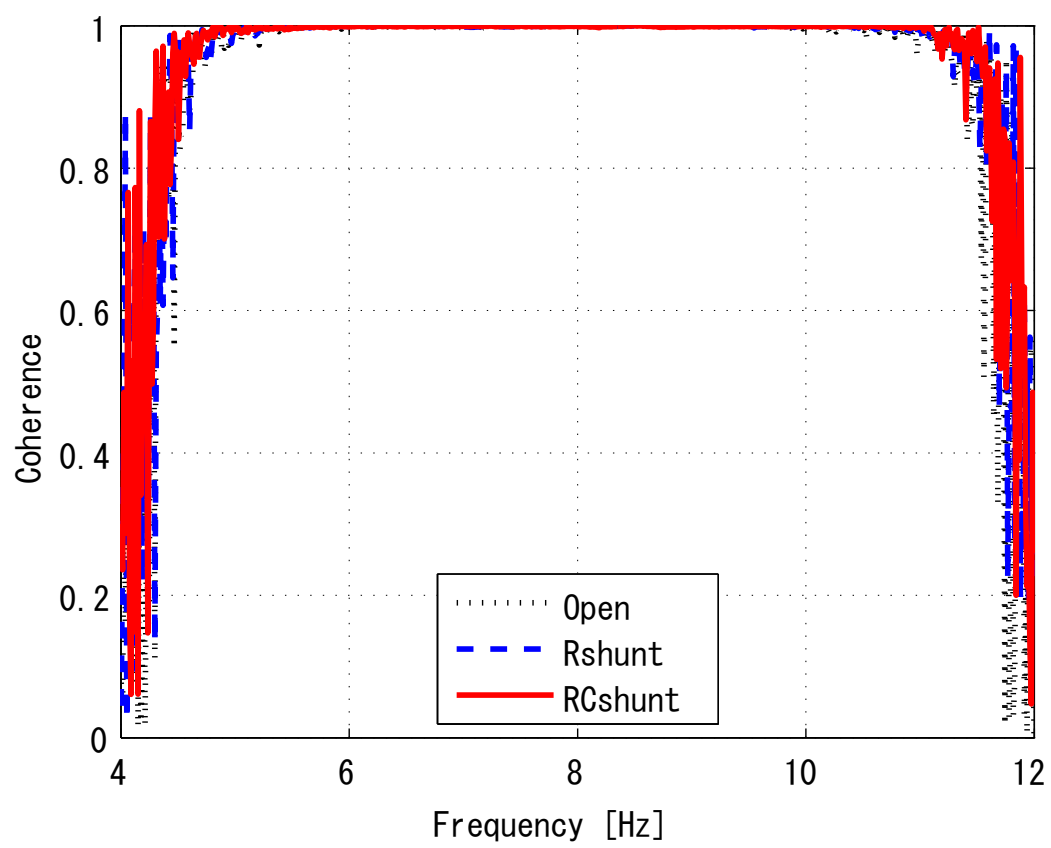

Fig. 12 Coherence in the experiment

図 6 と図 7 より, 推定されたモデルの応答が実験データによく一致していることから推定されたパラメータの 誤差は小さいと考えられる。しかし受動制振実験において，僅かなパラメータ誤差が制振性能に大きく影響する ことが動吸振器では知られているため検証が必要となる. 図 11 から R シャント回路接続時では端子間開放と比べ て約 $-19.2[\mathrm{~dB}], \mathrm{RC}$ シャント回路接続時では約 $-26.0[\mathrm{~dB}]$ 低減されていることが確認できた。つまり共振周波数 付近での最大振幅が $\mathrm{R}$ シャント回路接続時では約 $1 / 9$ に, RC シャント回路接続時では約 $1 / 20$ 以下に抑えられて いることが確認でき，十分に高い制振性能が発揮できている.

図 9 と図 11 を比較すると, R シャント回路接続時においては理論解析と制振実験の結果がほぼ一致しているこ 
とが確認できる，一方， $\mathrm{RC}$ シャント回路接続時の理論解析においては，1 個のピークが 2 個のピークに分かれる 形で制振されているという点で, 制振実験の結果と定性的に一致する. 理論解析では 2 個のピークの高さがほぼ 一致するのに対し, 制振実験では 2 個のピークの高さが異なるという意味で, 定量的に違いがみられる. しかし, 理論解析と制振実験での最大ピークの高さがほぼ一致する (理論解析 : $-27.4[\mathrm{~dB}]$, 制振実験 : $-26.0[\mathrm{~dB}]$ ) ことか ら, 制振実験は理論解析と同様の制振性能を達成したと判断できる.

\section{6. 結 言}

電磁アクチュエータのモデル化と支配方程式の導出, 電磁アクチュエータの端子間における電気アドミタンス伝 達関数の導出を行った. 得られた電気系と機械系が結合された電気アドミタンスと結合なしの電気アドミタンス とを比較することで, 機械系の固有角振動数付近の電気アドミタンスが重要であることを考察した．そして，固 有角振動数付近の電気アドミタンス計測のみで電気系だけでなく, 機械系と電気機械結合系のパラメータも变位・ 速度センサや加振用のアクチュエータを使用せずに推定可能であることを示した. 次に電気アドミタンス周波数 応答から非線形最小二乗法と, 非線形最小二乗法に必要な初期值を求める際などにも利用できる線形最小二乗法 によるパラメータ推定手法を提案した. 線形最小二乗法, 非線形最小二乗法と順にパラメータ推定実験を行い, 各 パラメータ值が推定可能であることを実験によって示した.

次に推定したパラメータ值から動吸振器の定点理論によりシャント回路を設計し, 電磁シャント制振実験を行っ た。 パラメータ推定值を用いて最適設計を行った実験結果から, パラメータ推定值は妥当であることを示した。

本論文で提案したパラメータ推定手法を用いることで, 外部センサや加振用アクチユエータを必要とせずにパ ラメータ推定から電磁シャント制振までを行うことができるため, より装置のコスト低減や簡単化を行うこと可 能である. また, 電磁シャント制振に限らず電磁アクチュエータを使用する際には, 電磁アクチュエータのパラ メータ (特に電気機械結合係数) を必要とすることが多いため, 本推定手法は電磁シャント制振以外の制振手法に も有効と予想できる.

\section{文献}

Behrens, S., Fleming, A.J. and Moheimani, S.O.R., Passive vibration control via electromagnetic shunt damping, IEEE/ASME Transactions on Mechatronics, Vol. 10, No. 1 (2005), pp. 118-122.

Boldea, I. and Nasar, S.A., Linear electric actuators and generators, IEEE Transactions on Energy Conversion, Vol. 14, No. 3 (1999), pp. 712-717.

Hanson, B. and Levesley, M., Self-sensing applications for electromagnetic actuators, Sensors and Actuators A: Physical, Vol. 116, No. 2 (2004), pp. 345-361.

井上剛志, 石田幸男, 角正貴, 電磁共振ダンパによる振動制御, 日本機械学会論文集 C 編, Vol. 70, No. 697 (2004), pp. 2565-2572.

MathWorks, lsqnonlin: Optimization Toolbox, available from <http://www.mathworks.com/help/optim/ug/lsqnonlin.html >, (参照日 2015 年 2 月 19 日).

Niederberger, D., Behrens, S., Fleming, A.J., Moheimani, S.O.R. and Morari, M., Adaptive electromagnetic shunt damping, IEEE/ASME Transactions on Mechatronics, Vol. 11, No. 1 (2006), pp. 103-108.

Niu, H., Zhang, X., Xie, S. and Wang, P., A new electromagnetic shunt damping treatment and vibration control of beam structures, Smart Materials and Structures, Vol. 18, No. 4 (2009), p. 045009.

Preumont, A., Vibration control of active structures, an introduction, 3rd edition, Springer (2011).

Rao, S.S., Mechanical vibration, 5th edition, Prentice Hall (2011).

高木賢太郎, 井上剛志, 宮地智也, ディジタル仮想インピーダンス回路を用いた電磁シャント制振, 日本機械学会論 文集 C 編, Vol. 78, No. 786 (2012), pp. 474-488.

Texas Instruments, LM675 Power Operational Amplifier, available from $<$ http://www.ti.com/lit/ds/symlink/lm675.pdf $>$, p. 4, Fig. 9, (参照日 2015 年 2 月 20 日).

Zhu, S., Shen, W. and Qian, X., Dynamic analogy between an electromagnetic shunt damper and a tuned mass damper, Smart Materials and Structures, Vol. 22, No. 11 (2013), p. 115018. 


\section{References}

Behrens, S., Fleming, A.J. and Moheimani, S.O.R., Passive vibration control via electromagnetic shunt damping, IEEE/ASME Transactions on Mechatronics, Vol. 10, No. 1 (2005), pp. 118-122.

Boldea, I. and Nasar, S.A., Linear electric actuators and generators, IEEE Transactions on Energy Conversion, Vol. 14, No. 3 (1999), pp. 712-717.

Hanson, B. and Levesley, M., Self-sensing applications for electromagnetic actuators, Sensors and Actuators A: Physical, Vol. 116, No. 2 (2004), pp. 345-361.

Inoue, T., Sumi, M. and Ishida, Y., Vibration control using electro-magnetic resonant shunt damper, Transactions of the Japan Society of Mechanical Engineers, Series C, Vol. 70, No. 697 (2004), pp. 2565-2572 (in Japanese).

MathWorks, lsqnonlin: Optimization Toolbox, available from <http://www.mathworks.com/help/optim/ug/lsqnonlin.html>, (accessed on 19 February, 2015).

Niederberger, D., Behrens, S., Fleming, A.J., Moheimani, S.O.R. and Morari, M., Adaptive electromagnetic shunt damping, IEEE/ASME Transactions on Mechatronics, Vol. 11, No. 1 (2006), pp. 103-108.

Niu, H., Zhang, X., Xie, S. and Wang, P., A new electromagnetic shunt damping treatment and vibration control of beam structures, Smart Materials and Structures, Vol. 18, No. 4 (2009), p. 045009.

Preumont, A., Vibration control of active structures, an introduction, 3rd edition, Springer (2011).

Rao, S.S., Mechanical vibration, 5th edition, Prentice Hall (2011).

Takagi, K., Inoue, T. and Miyachi, T., Electro-magnetic shunt damping with a digital virtual impedance circuit, Transactions of the Japan Society of Mechanical Engineers, Series C, Vol. 78, No. 786 (2012), pp. 474-488 (in Japanese).

Texas Instruments, LM675 Power Operational Amplifier, available from <http://www.ti.com/lit/ds/symlink/lm675.pdf>, p. 4, Fig. 9, (accessed on 20 February, 2015).

Zhu, S., Shen, W. and Qian, X., Dynamic analogy between an electromagnetic shunt damper and a tuned mass damper, Smart Materials and Structures, Vol. 22, No. 11 (2013), p. 115018. 